\title{
Forced Air Warming Device Failure Resulting in Smoke and Soot on a Surgical Patient
}

\author{
Moon T, Van Meter A, Vachhani S, Shah A, Zavala AM, Dang A, Potylchansky E, Williams UU, Lasala J and Tsai \\ January*
}

University of Texas, Anderson Cancer Center Department of Anesthesiology and Perioperative Medicine, USA

Submission: April 21, 2017; Published: May 03, 2017

*Corresponding author: University of Texas, Anderson Cancer Center Department of Anesthesiology and Perioperative Medicine, USA, Tel: 7133858484; Email: jtsai@mdanderson.org

\section{Introduction}

Forced air warming (FAW) devices are used in the operating room to helpmaintain normothermia during anesthesia and prevent complications of hypothermia. Proper use involves connecting the hose of the warming unit to a disposable blanket with a perforation pattern that evenly distributes heat across the patient's body. Multiple studies have shown the efficacy of FAW devices to be better than other widely used interventions such as circulating water mattresses [1]. However, as with most medical interventions there is a potential for complications with FAW devices. We present the case of a FAW device that malfunctioned after it became wet, depositing black soot on the patient.

\section{Case Report}

A 67 year old male patient with a history of hypertension, dyslipidemia, and lung cancer presented for a robotic-assisted left upper lobectomy. The patient was taken to the operating room where standard ASA monitors were applied. General anesthesia was induced, and the airway was secured with a 35 French left double lumen tube. A radial arterial line and addition IV lines were placed, after which the patient was positioned in the right lateral decubitus position. The patient's initial bladder temperature was $35.7^{\circ} \mathrm{C}$. A FAW blanket was applied to the patient's lower body, and the heating device was set to $43^{\circ} \mathrm{C}$. During the procedure, the patient's temperature decreased to $35.0^{\circ} \mathrm{C}$ and recovered to $35.8^{\circ} \mathrm{C}$ by the end of surgery. While closing the chest, the line isolation monitor alarm was heard and was investigated. A few minutes later smoke was noticed in the field, and the drapes were removed to identify the source. No flames were seen, and no obvious source of smoke was identified. Then, black punctate spots were noted on the sheets and the patient's lower extremities (Figure 1). Upon investigation, the black spots were soot deposited on the patient in the pattern of the perforation holes of the FAW blanket. The soot was wiped off the patient, and there was no injury to the patient. The blanket itself was dry, but the warming unit was sitting in irrigation thatspilled from the surgical field.

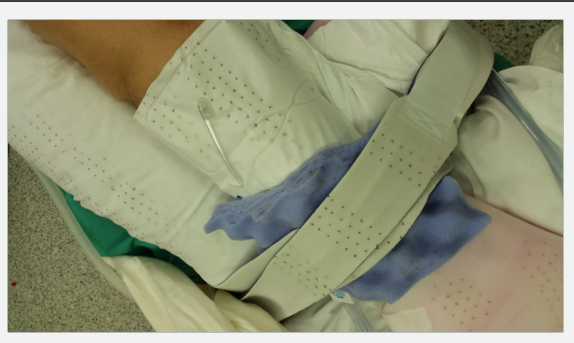

Figure 1: Black punctate spots were noted on the sheets and the patient's lower extremities.

\section{Discussion}

The Food and Drug Administration and Anesthesia Patient Safety Foundation discourage "hosing" [2-3], defined as the misuse of FAW devices by applying the hose directly to the patient or to a non-inflatable blanket. This misuse has resulted in various reports of first to third degree burns [4-6], including a reported amputation due to muscle necrosis. In our case, however, the FAW device was properly utilized with the hose attached to an inflatable blanket. Our institutional biomedical service evaluated this incident and device and concluded that the air-intake on the bottom of the unit entrained irrigation into the device, causing a short circuit within the unit. This electrical short created smoke inside the device, which was then blown out through the hose and deposited as soot through the perforation holes in the inflatable blanket. The unit was removed from service and returned to the manufacturer.

This is a near-miss case that could easily have resulted in a fire or electrical shock. The use of line isolation monitors is meant to decrease the risk of electrical shock in the operating room (OR). Common electrical circuits outside of the OR consist of a grounded system where an individual could be electrocuted by completing the electrical circuit. To provide additional safety in the $\mathrm{OR}$, the isolated electrical system is ungrounded and requires two faults in order to cause electrocution [7]. When the 
first fault occurs, the line isolation monitor will alarm. Electrical equipment should then be unplugged in reverse sequence until the alarm stops, which indicates the cause of the first fault. In this case, the FAW device was identified as the cause.

Documented complications from FAW use include an increased incidence of surgical site infections and some instances of burns due to misuse as mentioned above [4-6]. However, to our knowledge, electrical issues have not been reported. In order to prevent similar events and improve OR safety, we now attach our FAW devices to an elevated platform to ensure the device does not contact fluid on the floor.

\section{References}

1. Hye Young Kim, Kyu Chang Lee, Myeong Jong Lee, Mi-Na Kim, Ji-Sub Kim, et al. (2014) Comparison of the efficacy of a forced-air warming system and circulating-water mattress on core temperature and post-anesthesia shivering in elderly patients undergoing total knee arthroplasty under spinal anesthesia. Korean J Anesthesiol 66(5): 352357.

2. http://www.fda.gov/downloads/Safety/FDAPatientSafetyNews/ UCM417771.pdf.

3. http: / / w w w.apsf.org/newsletters/html/2002/ spring/13warmingdevices.htm

4. Truell KD, Bakerman PR, Teodori MF, Maze A (2000) Third-degree burns due to intraoperative use of a Bair Hugger warming device. Ann Thorac Surg 69: 1933-1934.

5. Chung K, Lee S, Oh SC, Choi J, Cho HS (2012 Thermal burn injury associated with a forced-air warming device. Korean J Anesthesiol 62(4): 391-392.

6. Uzun G, Mutluoglu M, Evinc R, Ozdemir Y, Sen H (2010) Severe burn injury associated with misuse of forced-air warming device. J Anesth 24: 980-981.

7. Barash PG (2006) Clinical Anesthesia, $\left(5^{\text {th }}\right.$ edn). Philadelphia, USA, pp. 159-162.

\section{Your next submission with Juniper Publishers} will reach you the below assets

- Quality Editorial service

- Swift Peer Review

- Reprints availability

- E-prints Service

- Manuscript Podcast for convenient understanding

- Global attainment for your research

- Manuscript accessibility in different formats

( Pdf, E-pub, Full Text, Audio)

- Unceasing customer service

Track the below URL for one-step submission https://juniperpublishers.com/online-submission.php 